him five Japanese youths to be housed and started in educational courses akin to English ideas and outlook. Thereupon Williamson undertook the necessary supervision, and he discharged his responsibilities thoroughly. It is sufficient to mention the after careers of these students of English methods to show this. One, who became the Marquis Ito, framed, in course of time, his country's constitution; a second, afterwards Count Inouye, aroused and developed commerce; a third, Viscount Inouye, inaugurated the Japanese railway system ; a fourth, Viscount Yamao, became the first Minister of Public Works, and initiated a scheme of technological training, assisted by workers drawn from British sources. In all this early planning Williamson had a share, through his disinterested activity. The first contingent of youths was followed by a party of sixteen from Tokyo, sent by the Prince of Satsuma, also placed under Williamson's watchful eye. Among these were Mori, Yoshima, and Sameshima. Finally, just over half a century ago (1880), we find Williamson engaged in a research with Sakurai, the Japanese chemist, and others of his nationality.

\section{Imported Scientific Films and Museum Specimens}

By the Finance Act of 1925, a customs duty of $33 \frac{1}{3}$ per cent was placed upon films imported into Great Britain. During the debate on the Finance Act of 1928, Capt. Ian Fraser, M.P., moved an amendment exempting from duty " cinematograph films . . . certified by the Royal Society of London for promoting Natural Knowledge to be solely an illustration of scientific investigation for exhibition before members of a recognised scientific body and imported only for the purpose of such exhibition free of charge". This amendment was accepted, and proved to be a small but much appreciated boon to scientific workers and others, who obviously benefit by the free international exchange of films recording their investigations. The new Import Duties Bill did not include such films in its list of imports exempt from duty, and Capt. Fraser put down an amendment the object of which was to retain the privilege. This amendment has now been taken over by the Chancellor of the Exchequer as an official amendment, and was incorporated in the Bill on report stage on Feb. 25. In a letter in the Times of Feb. 27, Sir Henry Wellcome refers to the position of material for exhibition in museums. A clause has been added to the Import Duties Bill exempting such material when it is more than a hundred years old, but this will not cover natural history, ethnographical, and other specimens required by research workers. The Museums Association, in a letter from its honorary secretary, Mr. D. W. Herdman, has endorsed Sir Henry Wellcome's statement, adding that its views have already been communicated to the Chancellor of the Exchequer. Museum material is clearly on the same footing as printed books, and we hope that it will be possible similarly to exempt it from import duty.

Prof. C. V. Boys's Apparatus at the Science Museum

Prof. C. V. Boys has recently presented to the Science Museum, South Kensington, some very interest- ing examples of his early experimental work. His use of quartz is shown in one case, where the bow which he employed in 1889 in the preparation of quartz fibres by the well-known 'bow-and-arrow' method is exhibited, together with examples of arrows used with it. Several of the fibres made by him in this way are exhibited, as well as the first quartz bulb ever blown. Soon after his successful production of quartz fibres, Prof. Boys utilised this material in an attempt to determine the constant of gravitation with a modified form of the Cavendish apparatus. He showed that increase of sensitivity could be accompanied by a considerable reduction in size, thus greatly reducing convection troubles. A small experimental apparatus made in 1889 served to demonstrate that consistent and accurate results could be obtained in this way, and as a result of the experience thus gained, a somewhat larger apparatus was made and used between 1889 and 1894 for the determination of the gravitational constant. Both instruments are now exhibited together, and form a permanent record of Boys's classical determination of this most important constant. In addition to the above, the following pieces of apparatus due to Prof. Boys are also on exhibition : the original experimental radio-micrometer, a portion of a new form of difference engine, and two electrometers, both dating from about 1891 .

\section{Scientific Research at the British Museum}

By the establishment in April 1931 of the Research Laboratory at the British Museum as a permanent institution under the control of the Trustees, the experimental stage of the undertaking, which had been continued by the Treasury and the Department of Scientific and Industrial Research for no less than eleven years, was brought to a successful conclusion. In a paper read before the Royal Society of Arts on Feb. 24, the Director of Scientific Research, Dr. Alexander Scott, indicated the nature and variety of the work carried out in his laboratory and described some of the results which have been obtained. In dis covering the best means of restoring and preserving museum objects, it is essential first to learn all that is possible regarding the previous history of each specimen; neglect of this essential has, in the past, led to many failures and has earned scientific men an evil reputation. The establishment of the research department on a permanent basis, however, is clear proof that the custodians of the nation's treasures have confidence in the methods which have been devised with so much care and applied with so much success.

\section{Restoration and Preservation in Museums}

DR. Scort referred to the disintegration of stone objects arising from the crystallisation of salts contained in the porous material, and to the extraction of the salts by means of wet paper pulp; salts are also removed from fragile brick tablets by first applying a celluloid coating, and then diffusing the salts into distilled water. Stains on old manuscripts can frequently be removed by the application of pyridine, and brown marks on water-colour pictures by the application of a solution of chloramine- $T$ '. The treatment of 'bronze 